\title{
Removal of model contaminants from water by porous carbons obtained through carbonization of poly(ethylene terephthalate) mixed with some magnesium compounds
}

\author{
J. Karolczyk $\cdot$ M. Janus $\cdot$ J. Przepiórski
}

Published online: 6 April 2012

(c) The Author(s) 2012. This article is published with open access at Springerlink.com

\begin{abstract}
Porous carbons were prepared through carbonization of poly(ethylene terephthalate) contained in mixtures with either light basic magnesium carbonate, or magnesium carbonate, or magnesium hydroxide, or magnesium oxide. Pore structure of the obtained carbon materials was presented in relation to a kind of magnesium compound and weight ratio of the raw materials used for preparations. Additionally, an influence of the preparation temperature on the porosity and the pore creation mechanism are briefly discussed. The carbons obtained were tested as sorbent materials for elimination of model contaminants from water. For that purpose, removal of several pollutants of different molecular weights including phenol, Basic Red 18 dye, and Reactive Red 198 dye is presented and discussed in relation to the porosity of the prepared materials.
\end{abstract}

Keywords Poly(ethylene terephthalate) - Porous carbon . Adsorption · Phenol · Basic Red 18 - Reactive Red 198

$\begin{array}{ll}\text { Abbreviations } \\ \text { PET } & \text { Poly(ethylene terephthalate) } \\ \text { BMC } & \text { Light basic magnesium carbonate } \\ \text { Decomp. } & \text { Decomposition } \\ \text { RR198 } & \text { Reactive Red } 198\end{array}$

J. Karolczyk · J. Przepiórski ( $₫)$

Institute of Chemical and Environmental Engineering, West Pomeranian University of Technology, ul. Pułaskiego 10, 70-322 Szczecin, Poland

e-mail: jacek.przepiorski@zut.edu.pl

\section{Janus}

Department of Sanitary Engineering, West Pomeranian University of Technology, al. Piastów 50, 70-310 Szczecin, Poland
BR18
Basic Red 18
XRD $\mathrm{X}$-ray diffraction
TPD
The temperature programmed desorption

\section{Introduction}

One of the major attributes of activated carbon is its ability to remove pollutants residing at low concentrations in fluid effluents. For that reason, adsorption onto this porous material is a popular method to remove contaminants from liquid and gaseous streams [1-5]. Adsorptive properties of activated carbons are strongly dependent on their porous structure [6-8]. In general, adsorption of small molecules proceeds effectively in micropores and bigger species require larger pores to be effectively eliminated from the purified media. Hence, an efficient simultaneous removal of contaminants of various molecular sizes is expected to proceed on adsorbents abundant in both micropores and mesopores.

Activated carbons can be produced according to various procedures. Conventionally used physical activation consists of two steps, i.e. carbonization of a suitable carbon precursor followed by activation in steam or $\mathrm{CO}_{2}$ atmosphere at ca. $900{ }^{\circ} \mathrm{C}$ [6, 9-11]. Besides, a chemical processes usually employing chemical activators like $\mathrm{ZnCl}_{2}$ or $\mathrm{H}_{3} \mathrm{PO}_{4}$ are also in use [6,11-15]. Natural precursors like coals or wood are the most frequently used raw materials to produce activated carbons [14-16]. Nevertheless, much attention has been paid to invent alternative methods employing synthetic materials as carbon precursors [17-22]. Additionally, in order to simplify the preparation procedure, one-step processes are often proposed. Inagaki et.al. reported a method to obtain mesoporous 
carbons by carbonization of polymeric precursors (e.g. poly(vinyl alcohol, poly(ethylene terephthalate)) or pitch contained in a mixture with some magnesium compounds including oxide, citrate, or gluconate, followed by removal of inorganics from the obtained products [20-23]. In this way highly porous carbon materials could be obtained without any activation process. As stated by the authors, both area and size of mesopores in resultant nanoporous carbons were strongly dependent on the size of $\mathrm{MgO}$ particles formed from their precursors during preparation process. A successful preparation of nanoporous carbons from polymeric precursor was also described in our previous paper [18]. As distinct from the works by the other teams, thermally unstable basic magnesium carbonate (BMC) was used as $\mathrm{MgO}$ precursor and poly(ethylene terephthalate) (PET) served as the carbon source. After simple pyrolysis of the BMC/PET mixtures, $\mathrm{MgO}$ newly formed was removed from the product. In this manner nanoporous carbons revealing high contributions of both micro- and mesopores could be obtained. As explained in the work in details, development of mesopores was due to $\mathrm{MgO}$ presence. On the other hand, gaseous products $\left(\mathrm{CO}_{2}\right.$ and $\mathrm{H}_{2} \mathrm{O}$ ) of $\mathrm{BMC}$ decomposition reacted with the char formed from PET and thus micropores were created. Hence, obtained porous carbons revealed bimodal pore structure that to some extent could be controlled by the ratio of BMC and PET used for preparations. Taking into account above findings, we have extended the gamut of $\mathrm{MgO}$ precursors potentially capable to reveal an analogous effect like the BMC used in the earlier work. The novelty of this work is use of both $\mathrm{Mg}(\mathrm{OH})_{2}$ and $\mathrm{MgCO}_{3}$ as pore creating agents. The compounds were thought to be suitable for that purpose because both of them undergo thermal decomposition to $\mathrm{MgO}$ and suitable gases, according to following reaction schemes:

$\mathrm{Mg}(\mathrm{OH})_{2} \rightarrow \mathrm{MgO}+\mathrm{H}_{2} \mathrm{O}$ (decomp. below $360{ }^{\circ} \mathrm{C}$ [24])

$\mathrm{MgCO}_{3} \rightarrow \mathrm{MgO}+\mathrm{CO}_{2}$ (decomp. below $550{ }^{\circ} \mathrm{C}$ [25])

Hence, we expected to obtain new porous carbon materials of bimodal character, rich in both micropores and mesopores, and therefore being potentially capable to adsorb contaminants of a wide range of molecular sizes. In order to examine performance of all the prepared materials as prospective adsorbents, adsorption of three different model contaminants from water was studied with respect to the textural parameters of the porous carbons.

Partial gasification of the char formed from PET by water released from the magnesium hydroxide was already confirmed in our previous work [26]. Since no results concerning pyrolysis of $\mathrm{MgCO}_{3} / \mathrm{PET}$ mixtures were reported, a brief discussion on the pore creation mechanism in this system is also provided.

\section{Experimental}

\subsection{Materials and preparations}

In this work four sorts of porous carbons prepared from the PET contained in mixtures with different magnesium compounds were studied. The materials were prepared according to the analogous procedures consisting in carbonization of the carbon precursor in mixtures with either $\mathrm{MgO}$ precursor (BMC, or $\mathrm{MgCO}_{3}$, or $\mathrm{Mg}(\mathrm{OH})_{2}$ ) or $\mathrm{MgO}$ itself, followed by removal of the residual inorganics by means of acid-washing. Preparation method for the porous carbon materials obtained from $\mathrm{MgO} / \mathrm{PET}$ and $\mathrm{BMC} / \mathrm{PET}$ was already described in details in our earlier work [18]. In order to prepare two other sorts of carbon, $\mathrm{Mg}(\mathrm{OH})_{2} / \mathrm{PET}$ and $\mathrm{MgCO}_{3} / \mathrm{PET}$ mixtures were pyrolysed at three temperatures, 550,700 , and $850{ }^{\circ} \mathrm{C}$, under flow of high purity $(99.999 \%)$ argon gas. The inorganics included in the obtained products were washed out using excessive amounts of aqueous $\mathrm{HCl}$ solution and distilled water. Magnesium carbonate $\left(\mathrm{MgCO}_{3}\right.$, Sigma-Aldrich, Germany) of analytic grade and reagent grade magnesium hydroxide $\left(\mathrm{Mg}(\mathrm{OH})_{2}, 95 \%\right.$, Fluka (Germany) were used in these cases as $\mathrm{MgO}$ precursors. A commercial grade PET purchased from Elana S.A. (Poland) served as the carbon precursor. Analytical grade phenol (Sigma-Aldrich, Germany), commercial grade Reactive Red 198 (CAS No. 145017-98-7) and Basic Red 18 (CAS No.14097-03-1) dyes, both obtained from Boruta-Kolor Sp. z o. o., Poland, were employed as model adsorbates.

\subsection{Methods}

$\mathrm{X}$-ray diffraction pattern presented in this work was measured with use of Philips X'Pert PRO diffractometer

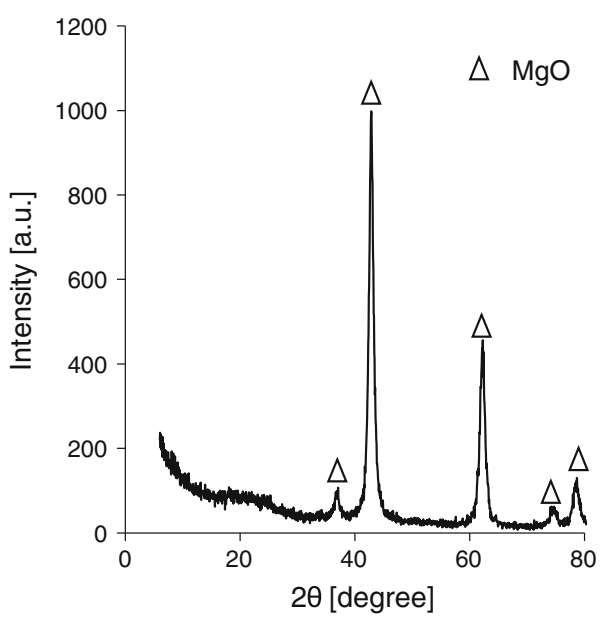

Fig. 1 XRD pattern of $\mathrm{MgCO}_{3} / \mathrm{PET}$ (50/50) mixture after heating at $850{ }^{\circ} \mathrm{C}$ 


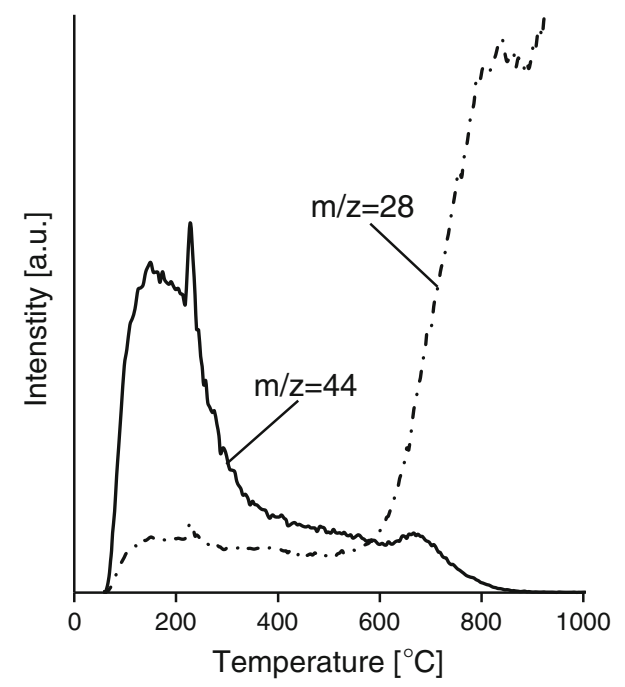

Fig. 2 TPD profile of carbon material $\left(\mathrm{MgCO}_{3} / \mathrm{PET} 70 / 30\right)$ preheated to $700{ }^{\circ} \mathrm{C}$ operating with the $\mathrm{Cu} \mathrm{K}_{\alpha}(\lambda=154,056 \AA)$ radiation. Nitrogen adsorption/desorption isotherms at $77 \mathrm{~K}$ were measured using Quadrasorb SI apparatus (Quantachrome Instruments, USA). Prior to the measurements samples were subjected to $24 \mathrm{~h}$-long degassing carried out under high vacuum and at $290{ }^{\circ} \mathrm{C}$. The specific surface area values were determined from multi-point adsorption branches of the attained isotherms, applying Brunauer-EmmetTeller (BET) equation. The total surface area values $\left(S_{\text {total }}\right)$, external surface areas $\left(S_{\text {ext }}\right)$, and micropore areas $\left(S_{\text {micro }}\right)$, were calculated using $\alpha_{\mathrm{s}}$ method. The DubininRadushkevich equation was used to calculate micropore volumes $\left(\mathrm{V}_{\text {microDR }}\right)$ from adsorption branches of the isotherms. The total pore volumes $\left(\mathrm{V}_{\text {tot0.95 }}\right)$ were determined from the amounts of nitrogen adsorbed at relative pressure $\mathrm{p} / \mathrm{p}_{\mathrm{o}}=0.95$. Finally, the volume of mesopores $\left(\mathrm{V}_{\text {meso }}\right)$ could be calculated by subtracting the micropore volume from the total pore volume. In order to determine pore size
Fig. 3 Nitrogen adsorption/ desorption isotherms measured for porous carbons obtained from: a $\mathrm{MgCO}_{3} / \mathrm{PET} 70 / 30$ mixture at different preparation temperatures, $\mathbf{b} \mathrm{MgCO}_{3} / \mathrm{PET}$ mixtures with different weight ratios of the components, prepared at $850{ }^{\circ} \mathrm{C}, \mathbf{c ~} \mathrm{Mg}(\mathrm{OH})_{2} /$ PET 70/30 mixture at different treatment temperatures, and d $\mathrm{Mg}(\mathrm{OH})_{2} / \mathrm{PET}$ mixtures with different weight ratios of the components, prepared at $850{ }^{\circ} \mathrm{C}$
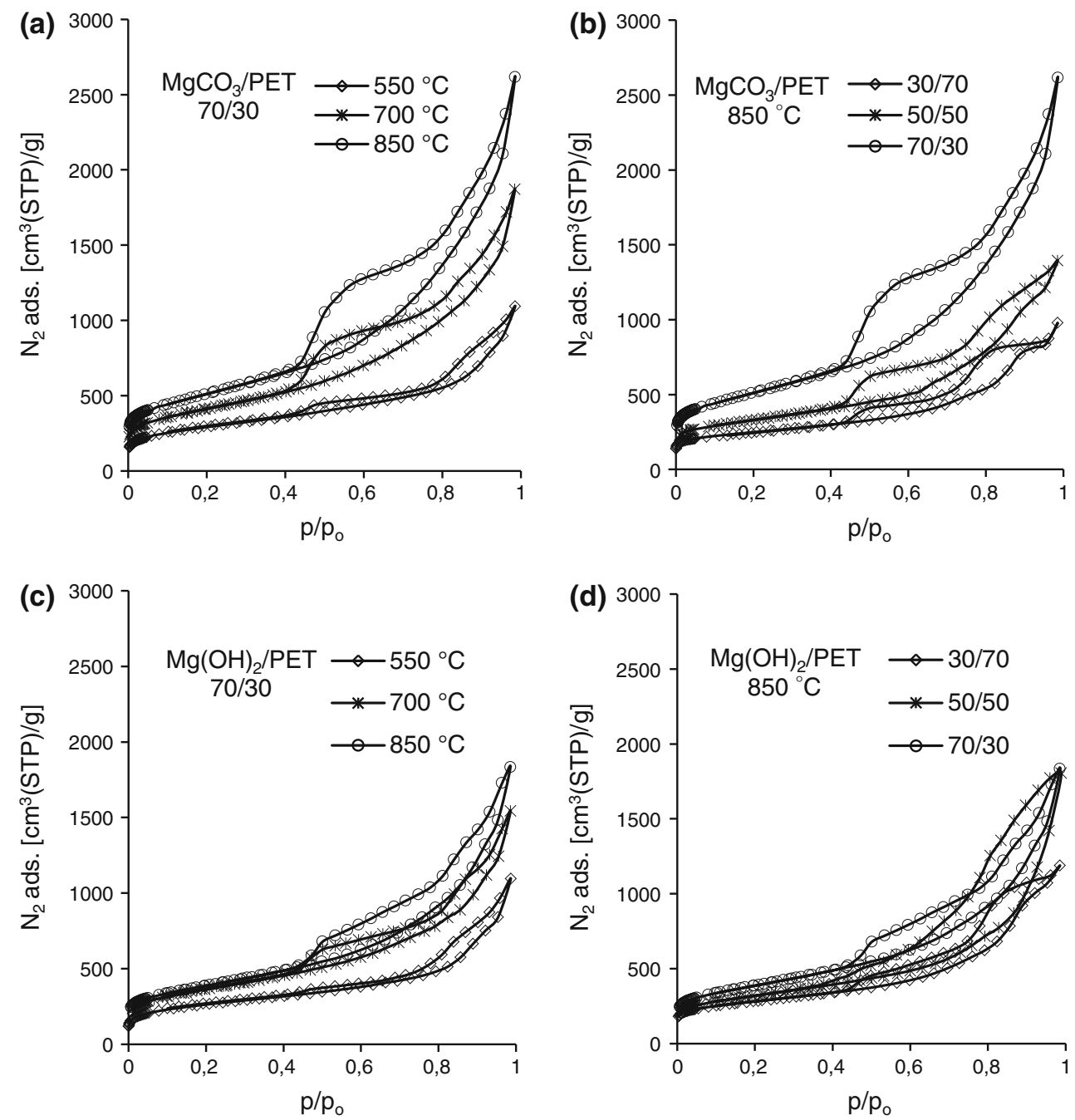

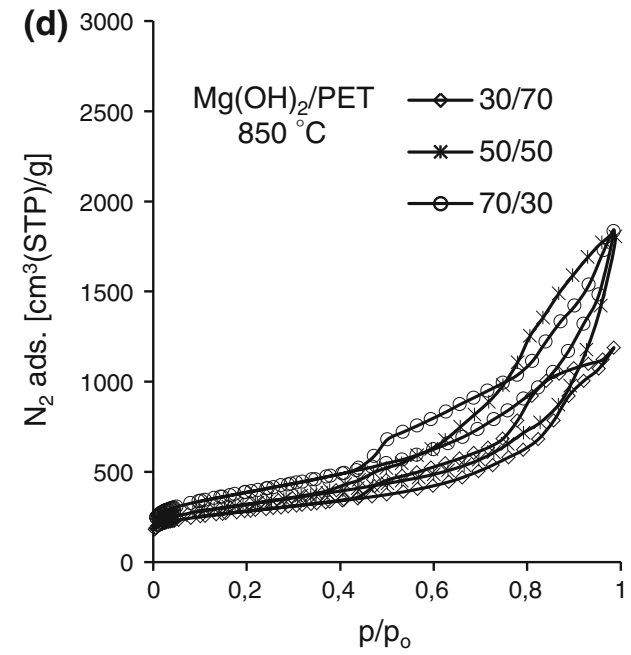


distributions in mesopore range, the Barrett, Joyner, and Halenda (BJH) method was applied to the $\mathrm{N}_{2}$ adsorption data.

Temperature programmed desorption (TPD) was examined using thermal desorption spectrometer (TDS1200 apparatus, ESCO Ltd., Japan) equipped with a quadrupole mass spectrometer. Evolution of $\mathrm{CO}_{2}$ and $\mathrm{CO}$ was continuously monitored on the basis of $\mathrm{m} / \mathrm{z}=44$ and $\mathrm{m} / \mathrm{z}=28$ signals, respectively. The measurement was carried out under a high vacuum (pressure below $10^{-6} \mathrm{~Pa}$ ) and sample was heated up to $1,000{ }^{\circ} \mathrm{C}$ at a heating rate of $60{ }^{\circ} \mathrm{C} / \mathrm{min}$. Prior to the TPD, sample was heated to $700{ }^{\circ} \mathrm{C}$ under argon gas flow.

Adsorption of phenol, Basic Red 18 dye (BR18), and Reactive Red 198 dye (RR198) onto obtained porous carbons was examined applying the batch method. For that purpose, flasks containing suitable amounts $(0-50 \mathrm{mg})$ of an individual carbon material were filled with $100 \mathrm{~cm}^{3}$ of aqueous solution of either phenol $\left(100 \mathrm{mg} / \mathrm{dm}^{3}\right)$ or BR18 $(30 \mathrm{mg} /$ $\left.\mathrm{dm}^{3}\right)$, or RR198 $\left(30 \mathrm{mg} / \mathrm{dm}^{3}\right)$, and then were thermostated for $2 \mathrm{~h}$ at $30{ }^{\circ} \mathrm{C}$, in a shaking water bath. Concentrations of each model contaminant were determined spectrophotometrically using Jasco V-530 UV-Vis spectrometer. In order to estimate concentration of phenol, BR18, and RR198, absorbances at $\lambda_{\max }=270 \mathrm{~nm}, \lambda_{\max }=480 \mathrm{~nm}$, and $\lambda_{\max }=516 \mathrm{~nm}$ were measured, respectively. The amount of an adsorbate adsorbed on activated carbons at equilibrium, $q_{e}$, was calculated according to the following equation:

$q_{e}=\frac{V\left(C_{i}-C_{e}\right)}{m}$

where $V\left[\mathrm{dm}^{3}\right]$ is the volume of solution used in the adsorption experiment, $C_{i}$ and $C_{e}$ are the initial and equilibrium concentrations of the adsorbate $\left(\mathrm{mg} / \mathrm{dm}^{3}\right)$, respectively, and $\mathrm{m}$ denotes mass of the adsorbent $(\mathrm{g})$ used.

\section{Results and discussion}

\subsection{Pyrolysis of $\mathrm{MgCO}_{3} / \mathrm{PET}$ mixtures and pore creation mechanism}

The XRD pattern presented in Fig. 1 has confirmed that heating of $\mathrm{MgCO}_{3} / \mathrm{PET}$ mixture to $850{ }^{\circ} \mathrm{C}$ resulted in obtaining carbonaceous material loaded with expected $\mathrm{MgO}$. Besides the oxide, stoichiometric amounts of $\mathrm{CO}_{2}$ must be formed in situ from the carbonate. Taking into consideration results of our earlier works [18, 26], occurrence of analogous effects was suspected in the pyrolysed

Table 1 Textural characteristics of activated carbons obtained at various temperatures from PET mixed with different magnesium compounds $\left(\mathrm{MgCO}_{3}, \mathrm{Mg}(\mathrm{OH})_{2}, \mathrm{BMC}, \mathrm{MgO}\right)$

\begin{tabular}{|c|c|c|c|c|c|c|c|c|c|}
\hline & \multirow{2}{*}{$\begin{array}{l}\text { Weight ratio } \\
\text { (wt. \%) }\end{array}$} & \multirow{2}{*}{$\begin{array}{l}\text { Temperature } \\
\left({ }^{\circ} \mathrm{C}\right)\end{array}$} & \multirow{2}{*}{$\begin{array}{l}\mathrm{S}_{\mathrm{BET}} \\
\left(\mathrm{m}^{2} / \mathrm{g}\right)\end{array}$} & \multicolumn{3}{|c|}{$\alpha_{\mathrm{s}}$ Analysis } & \multirow{2}{*}{$\begin{array}{l}\mathrm{V}_{\text {tot } 0.95} \\
\left(\mathrm{~cm}^{3} / \mathrm{g}\right)\end{array}$} & \multirow{2}{*}{$\begin{array}{l}\mathrm{V}_{\text {microDR }} \\
\left(\mathrm{cm}^{3} / \mathrm{g}\right)\end{array}$} & \multirow{2}{*}{$\begin{array}{l}V_{\text {meso }} \\
\left(\mathrm{cm}^{3} / \mathrm{g}\right)\end{array}$} \\
\hline & & & & $\begin{array}{l}\mathrm{S}_{\text {total }} \\
\left(\mathrm{m}^{2} / \mathrm{g}\right)\end{array}$ & $\begin{array}{l}\mathrm{S}_{\text {ext }} \\
\left(\mathrm{m}^{2} / \mathrm{g}\right)\end{array}$ & $\begin{array}{l}\mathrm{S}_{\text {micro }} \\
\left(\mathrm{m}^{2} / \mathrm{g}\right)\end{array}$ & & & \\
\hline \multirow[t]{5}{*}{$\mathrm{MgCO}_{3} / \mathrm{PET}$} & $30 / 70$ & 850 & 870 & 986 & 712 & 274 & 1.34 & 0.37 & 0.97 \\
\hline & $50 / 50$ & 850 & 1118 & 1189 & 852 & 337 & 1.97 & 0.46 & 1.51 \\
\hline & $70 / 30$ & 550 & 953 & 919 & 733 & 186 & 1.21 & 0.38 & 0.83 \\
\hline & & 700 & 1437 & 1408 & 1146 & 262 & 2.31 & 0.56 & 1.75 \\
\hline & & 850 & 1772 & 1756 & 1518 & 238 & 3.35 & 0.69 & 2.66 \\
\hline \multirow[t]{5}{*}{$\mathrm{Mg}(\mathrm{OH})_{2} / \mathrm{PET}$} & $30 / 70$ & 850 & 907 & 1008 & 622 & 385 & 1.70 & 0.38 & 1.32 \\
\hline & $50 / 50$ & 850 & 1049 & 1124 & 776 & 348 & 2.23 & 0.43 & 1.80 \\
\hline & $70 / 30$ & 550 & 875 & 836 & 643 & 193 & 1.34 & 0.36 & 0.98 \\
\hline & & 700 & 1253 & 1259 & 1029 & 239 & 1.92 & 0.51 & 1.41 \\
\hline & & 850 & 1302 & 1317 & 1019 & 298 & 2.03 & 0.52 & 1.51 \\
\hline \multirow[t]{5}{*}{$\mathrm{BMC} / \mathrm{PET}^{\mathrm{a}}$} & $30 / 70$ & 850 & 944 & 1088 & 470 & 618 & 1.25 & 0.39 & 0.86 \\
\hline & $50 / 50$ & 550 & 531 & 519 & 284 & 235 & 0.73 & 0.21 & 0.52 \\
\hline & & 700 & 1064 & 1150 & 677 & 473 & 1.39 & 0.42 & 0.97 \\
\hline & & 850 & 1049 & 1135 & 632 & 503 & 1.64 & 0.43 & 1.21 \\
\hline & $70 / 30$ & 850 & 1984 & 2063 & 1505 & 557 & 2.93 & 0.79 & 2.14 \\
\hline \multirow[t]{5}{*}{$\mathrm{MgO} / \mathrm{PET}^{\mathrm{a}}$} & $30 / 70$ & 850 & 713 & 882 & 390 & 492 & 1.12 & 0.32 & 0.80 \\
\hline & $50 / 50$ & 550 & 678 & 722 & 381 & 341 & 1.04 & 0.30 & 0.74 \\
\hline & & 700 & 799 & 915 & 332 & 584 & 1.27 & 0.35 & 0.92 \\
\hline & & 850 & 788 & 916 & 343 & 573 & 1.57 & 0.37 & 1.20 \\
\hline & $70 / 30$ & 850 & 763 & 958 & 379 & 579 & 1.28 & 0.35 & 0.93 \\
\hline
\end{tabular}

${ }^{\mathrm{a}}$ Data collected from [18] 
$\mathrm{MgCO}_{3} / \mathrm{PET}$ mixture. Hence, reaction between occluded $\mathrm{CO}_{2}$ and the char formed from PET contained in the pyrolysed mixture was considered as highly probable to proceed. In order to confirm these predictions, TPD from
$\mathrm{MgCO}_{3} / \mathrm{PET}$ material preheated to $700{ }^{\circ} \mathrm{C}$ was measured. Obtained results are presented in Fig. 2.

The TPD spectra confirmed an intensive evolution of $\mathrm{CO}_{2}$ from ca. $60{ }^{\circ} \mathrm{C}$ to over $300{ }^{\circ} \mathrm{C}$ followed by a less
Fig. 4 Mesopore size distribution curves (calculated by BJH method) for carbon materials prepared from a $\mathrm{MgCO}_{3} / \mathrm{PET}$ and $\mathbf{b} \mathrm{Mg}(\mathrm{OH})_{2} /$ PET mixtures

Fig. 5 Adsorption of phenol on activated carbons obtained at $850{ }^{\circ} \mathrm{C}$ from a $\mathrm{MgCO}_{3} / \mathrm{PET}$, b $\mathrm{Mg}(\mathrm{OH})_{2} / \mathrm{PET}$, c BMC/PET, d $\mathrm{MgO} / \mathrm{PET}$ mixtures
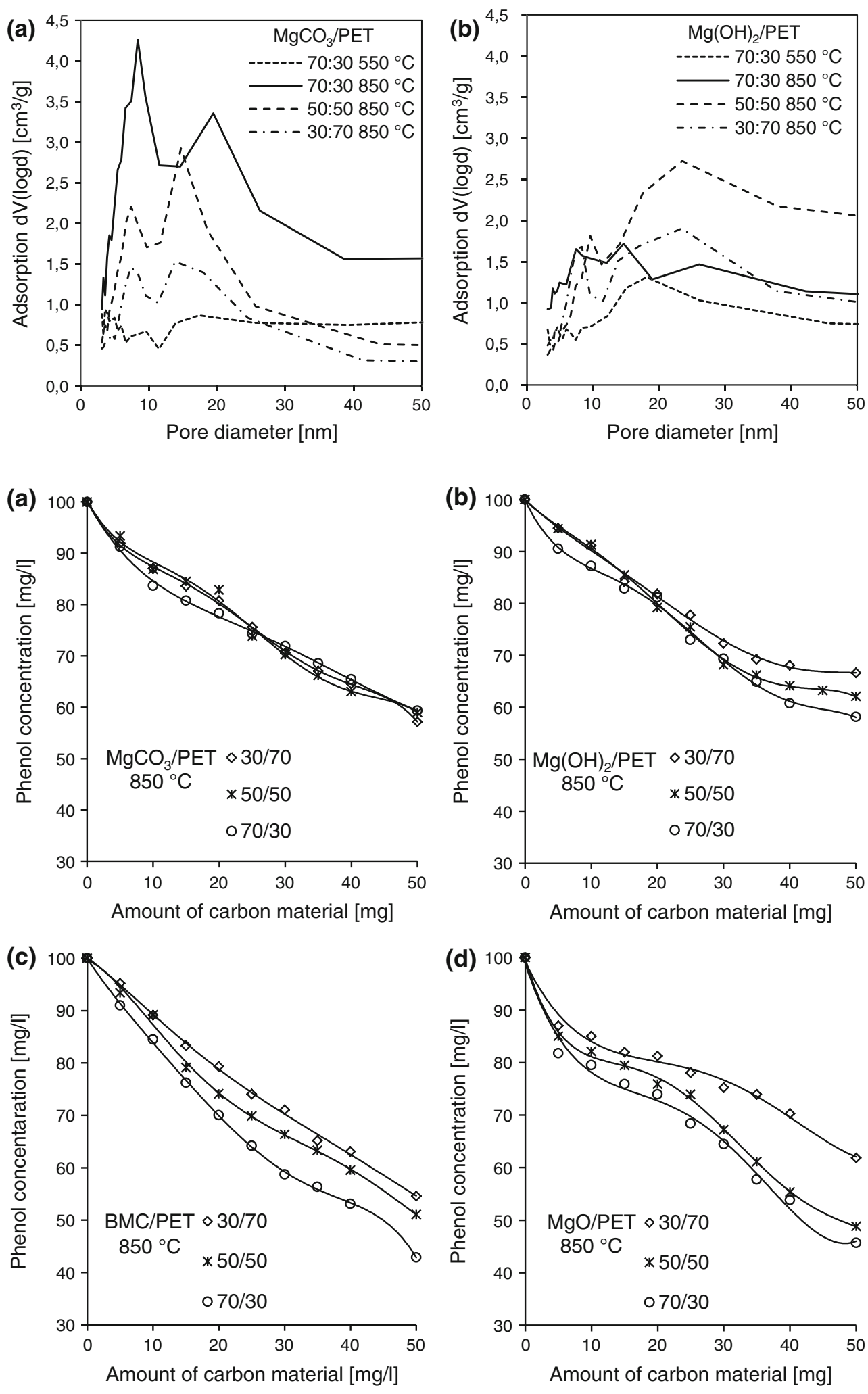
intensive release of the gas at higher temperatures, to ca. $800{ }^{\circ} \mathrm{C}$. In addition, intensive evolution of carbon monoxide (CO) could be confirmed at temperatures above $600{ }^{\circ} \mathrm{C}$. The results presented in Fig. 2 are convergent with those obtained for both BMC/PET and $\mathrm{Mg}(\mathrm{OH})_{2} / \mathrm{PET}$ systems. For that reason, formation of $\mathrm{CO}$ at the high temperatures was assumed to be due to the reaction between the carbon material (char) and $\mathrm{CO}_{2}$ formed from $\mathrm{MgCO}_{3}$. In view of above discussion, $\mathrm{MgCO}_{3}$ was confirmed to be an another example of magnesium compound that is capable to create porosity in carbon materials according to the analogous mechanism as reported in details elsewhere [18].

\subsection{Porosity and pore size distribution}

Results of nitrogen adsorption and desorption for BMC/ $\mathrm{PET}$ — and $\mathrm{MgO} / \mathrm{PET}$ — based carbons were already presented in our earlier report [18]. Therefore, in this work we show (Fig. 3) only appropriate results acquired for carbon materials obtained from $\mathrm{MgCO}_{3} / \mathrm{PET}$ and $\mathrm{Mg}(\mathrm{OH})_{2} / \mathrm{PET}$ mixtures.

Shapes of all the measured isotherms are resultant from type I and IV profiles according to the IUPAC classification [27]. Hence, apart from well-developed microporosity, all the materials reveal significant adsorption in mesopores that is confirmed by distinct hysteresis loops at relative pressures above around 0.5. As a rule, adsorption of nitrogen at $77 \mathrm{~K}$ increases along with both temperature of the preparation process and loading of magnesium compounds in raw mixtures. This is particularly manifested for carbons obtained from $\mathrm{MgCO}_{3} / \mathrm{PET}$ mixtures. Nevertheless, the general trends are convergent with those observed for nanoporous carbons prepared from PET included in the mixture with BMC [18].

The textural parameters characterizing structure of the carbon materials, calculated from nitrogen adsorption/ desorption isotherms, are listed in Table 1. Because this work summarizes adsorption behaviors of the materials prepared by our group from all the studied $(\mathrm{Mg}$
Fig. 6 Adsorption of phenol on activated carbons obtained from a $\mathrm{MgCO}_{3} / \mathrm{PET}$, b $\mathrm{Mg}(\mathrm{OH})_{2} /$ $\mathrm{PET}, \mathbf{c} \mathrm{BMC} / \mathrm{PET}, \mathbf{d} \mathrm{MgO} / \mathrm{PET}$ mixtures $(70 / 30$ or $50 / 50)$ at different temperatures
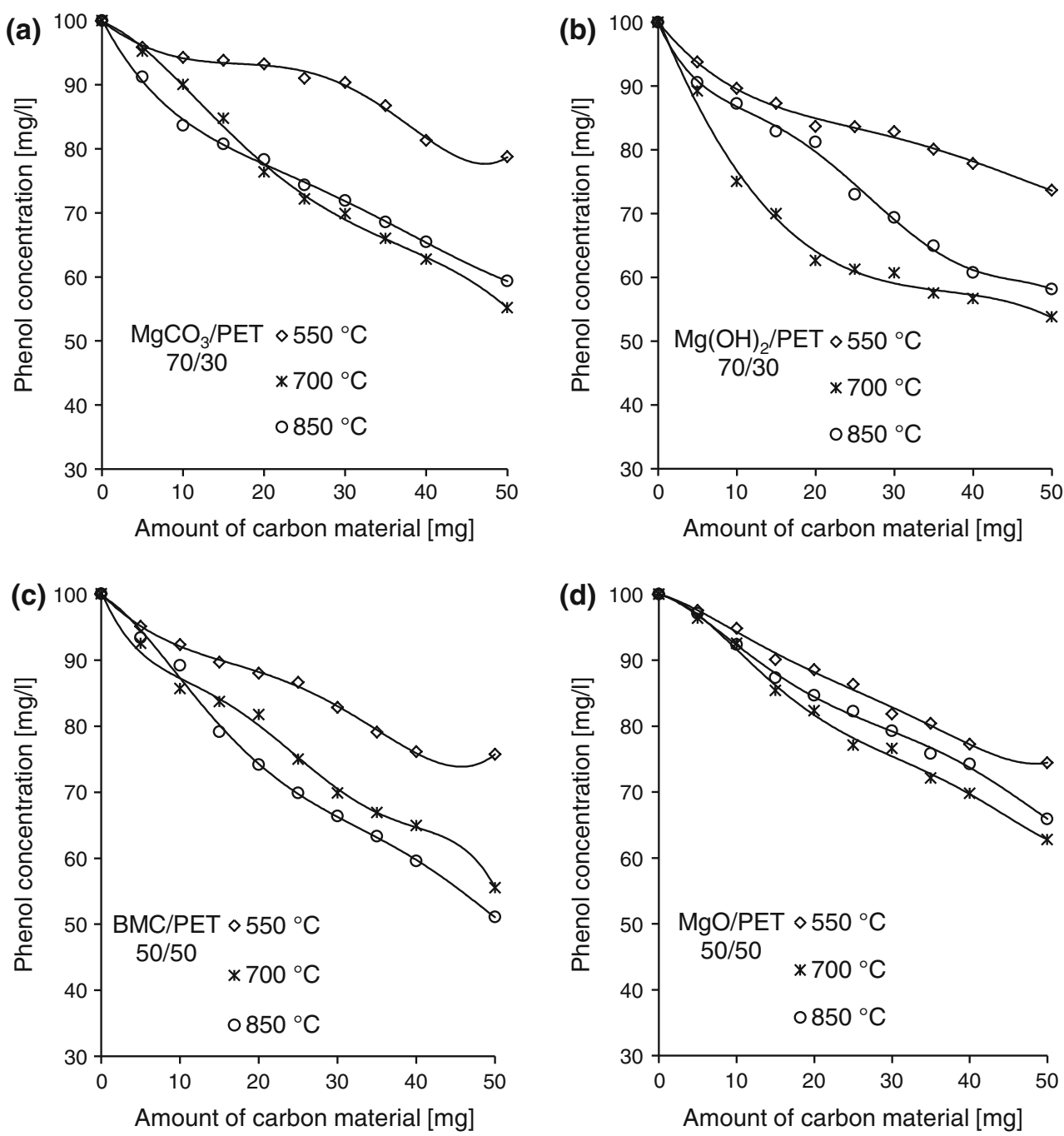
compound)/PET mixtures, pore parameters reported earlier for carbons obtained from $\mathrm{MgO} / \mathrm{PET}$ and BMC/PET are also included.

Regardless of magnesium compounds and temperatures used for preparations, all the carbon materials reveal high specific surface area ranging from over $500 \mathrm{~m}^{2} / \mathrm{g}$ to nearly $2,000 \mathrm{~m}^{2} / \mathrm{g}$, arising from both micropores and mesopores. Taking into account data listed in Tab. 1, several general observations could be drawn:

- Pore parameters determined for carbons prepared at $550{ }^{\circ} \mathrm{C}$ are generally lower than those calculated for carbons prepared at higher temperatures,

- The total areas revealed by nanoporous carbons prepared through pyrolysis of PET included in a mixture with decomposable magnesium is higher compared to values determined for carbons obtained from $\mathrm{MgO} / \mathrm{PET}$ systems,

- While carbons prepared from $\mathrm{MgO} / \mathrm{PET}$ exhibit predominant microporous character, mesoporosity dominates in the carbon materials prepared using $\mathrm{BMC}$, $\mathrm{MgCO}_{3}$, or $\mathrm{Mg}(\mathrm{OH})_{2}$,

Fig. 7 Adsorption of BR18 on activated carbons obtained from a $\mathrm{MgCO}_{3} / \mathrm{PET}, \mathbf{b} \mathrm{Mg}(\mathrm{OH})_{2} /$ PET, $\mathbf{c} \mathrm{BMC} / \mathrm{PET}$, and $\mathbf{d} \mathrm{MgO} /$ PET mixtures with different weight ratios of the components, all prepared at $850{ }^{\circ} \mathrm{C}$

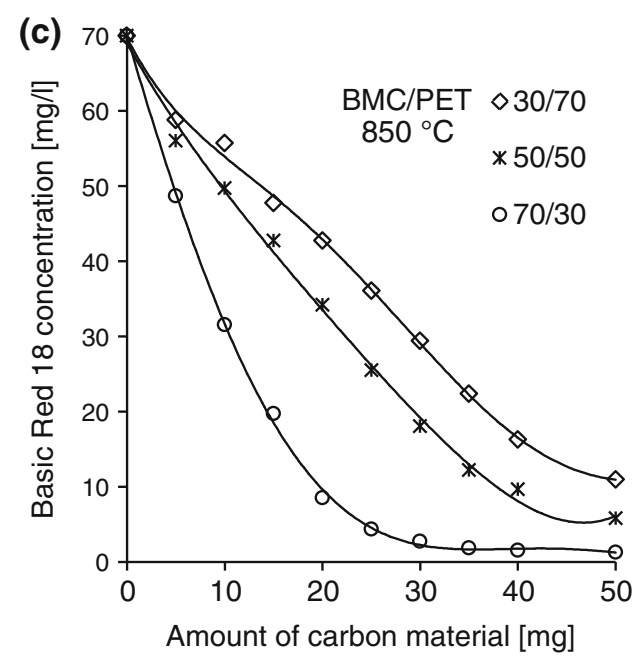

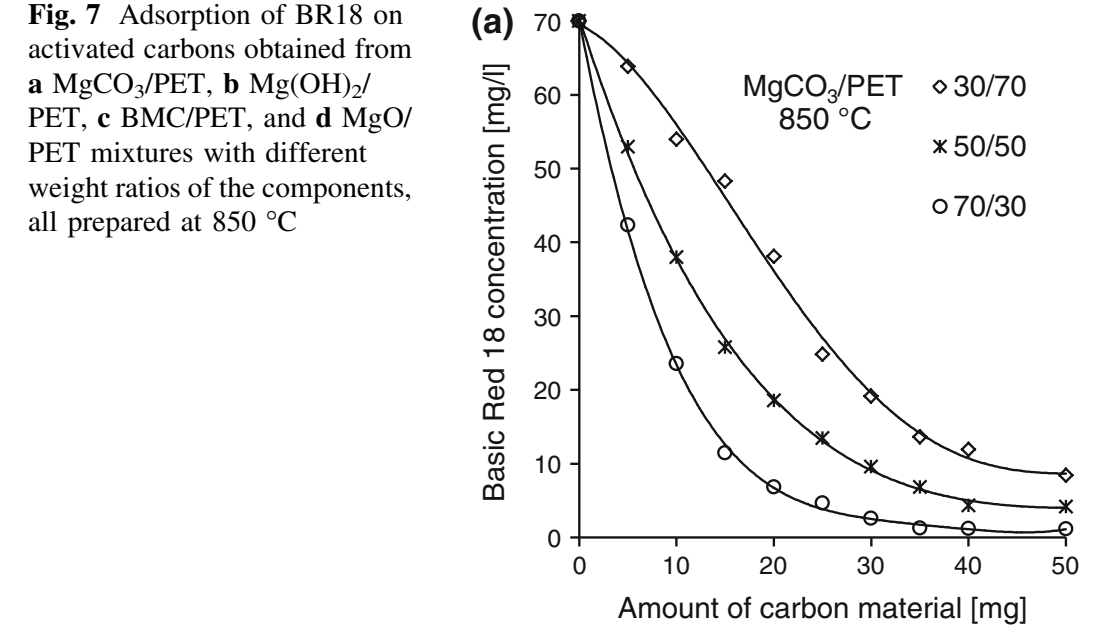

- Higher loadings of decomposable magnesium compounds in the raw mixtures are reflected by higher pore parameters of the resultant carbons,

- Pore parameters determined for carbons prepared from $\mathrm{MgO} / \mathrm{PET}$ mixtures are only a little influenced by $\mathrm{MgO}$ loadings in the starting mixtures and by preparation temperature.

As illustrated in Fig. 4, pore size distributions in the mesopore region determined for porous carbons prepared from the $\mathrm{MgCO}_{3} / \mathrm{PET}$ mixtures are different compared to carbons prepared from PET loaded with $\mathrm{Mg}(\mathrm{OH})_{2}$. The mesopore volume calculated for $\mathrm{MgCO}_{3} / \mathrm{PET}$-based carbons strongly depends on both $\mathrm{MgCO}_{3}$ content in the raw material and preparation temperature. This principally concerns mesopores ranging from 5 to ca. $25 \mathrm{~nm}$ in the width. In addition, the volume of mesopores within this width range depends noticeably on the preparation temperature. Hence, while the carbon prepared at $550{ }^{\circ} \mathrm{C}$ reveals low pore volume without a defined maxima, material obtained at $850{ }^{\circ} \mathrm{C}$ shows significant pore volume within the range, with two sharp maxima at pore widths ca. 8 and $20 \mathrm{~nm}$.
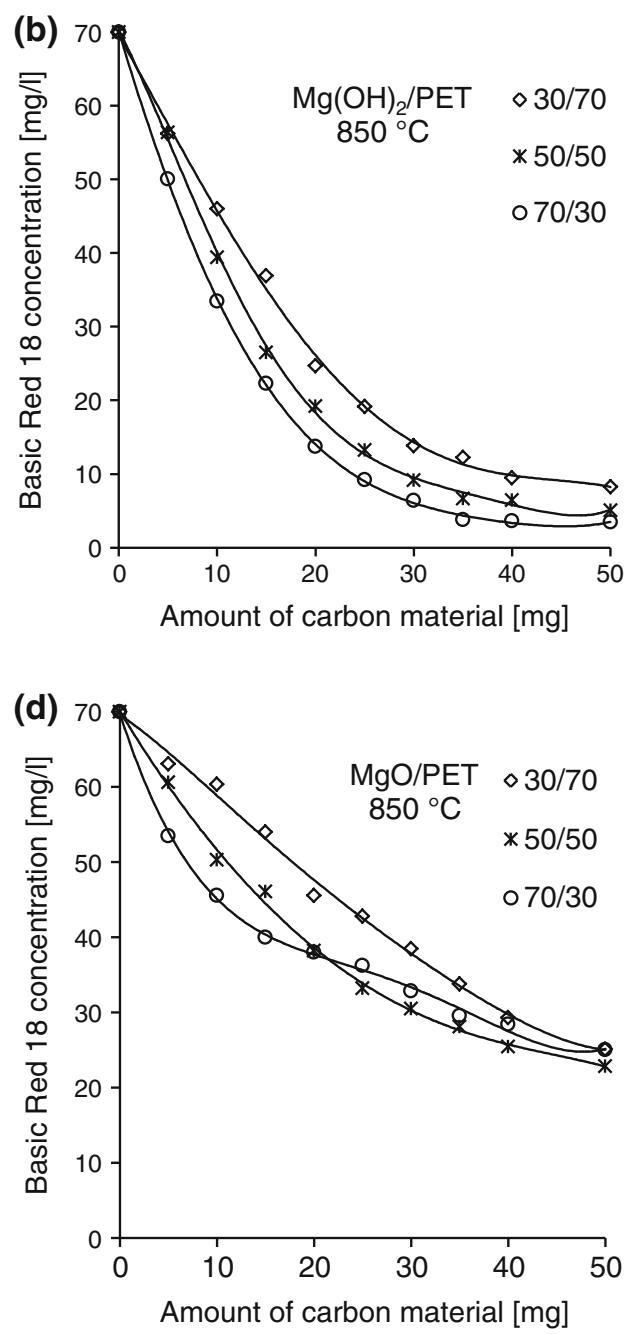
On the other hand, the carbons prepared from PET mixed with $\mathrm{Mg}(\mathrm{OH})_{2}$ demonstrate predominant share of larger mesopores (15-40 nm in width) and lower contribution of the smaller ones, ranging from 5 to $15 \mathrm{~nm}$ in width. Although pore size distributions in the mesopore range vary with the composition of the raw mixture, no clear trend could be observed in this case. Nevertheless, similar to $\mathrm{MgCO}_{3} / \mathrm{PET}$ system, application of the higher temperature for preparations results in obtaining products demonstrating higher mesopore volumes. In view of corresponding results reported for carbon materials prepared from $\mathrm{MgO} / \mathrm{PET}$ mixes [18], it may be stated that mesopore volumes revealed by both $\mathrm{MgCO}_{3} / \mathrm{PET}$ - and $\mathrm{Mg}(\mathrm{OH})_{2}$ - series carbons are higher. This must be an outcome of the action of $\mathrm{CO}_{2}$ and $\mathrm{H}_{2} \mathrm{O}$ on the char during the pyrolysis process.

\subsection{Adsorption of model contaminants}

Because of considerable volumes of micropores and mesopores, the nanoporous carbons were tested as adsorbents for model water contaminants of a wide range of molecular weights. For that purpose aqueous solutions of phenol (94 g/mol), BR18 (390 g/mol), and RR198 (968 g/mol) were used as media conveying the adsorbates.

\subsubsection{Removal of phenol from water}

Adsorption of phenol on the obtained porous carbons is illustrated by Figs. 5 and 6 .

All the examined adsorbents are to some extent capable to remove the contaminant from water. As it can be seen in Fig. 5a, b, regardless of $\mathrm{MgCO}_{3} / \mathrm{PET}$ and $\mathrm{Mg}(\mathrm{OH})_{2} /$ PET ratios used for preparations, the resulting adsorbents reveal comparable adsorption abilities towards phenol, ranging from 81 to $106 \mathrm{mg} / \mathrm{g}$. For comparison, adsorption of phenol on the carbons obtained from BMC/PET and $\mathrm{MgO} / \mathrm{PET}$ mixtures is generally a little higher and ranges from nearly 70 to $114 \mathrm{mg} / \mathrm{g}$. In addition, the removal efficiency tends to increase along with relative weight contents of magnesium compounds in the raw mixes,
Fig. 8 Adsorption of BR18 on activated carbons prepared at different temperatures from a $\mathrm{MgCO}_{3} / \mathrm{PET}, \mathbf{b} \mathrm{Mg}(\mathrm{OH})_{2} /$ $\mathrm{PET}$, $\mathbf{c} \mathrm{BMC} / \mathrm{PET}$, and $\mathbf{d} \mathrm{MgO} /$ PET mixtures $(70 / 30$ or $50 / 50)$
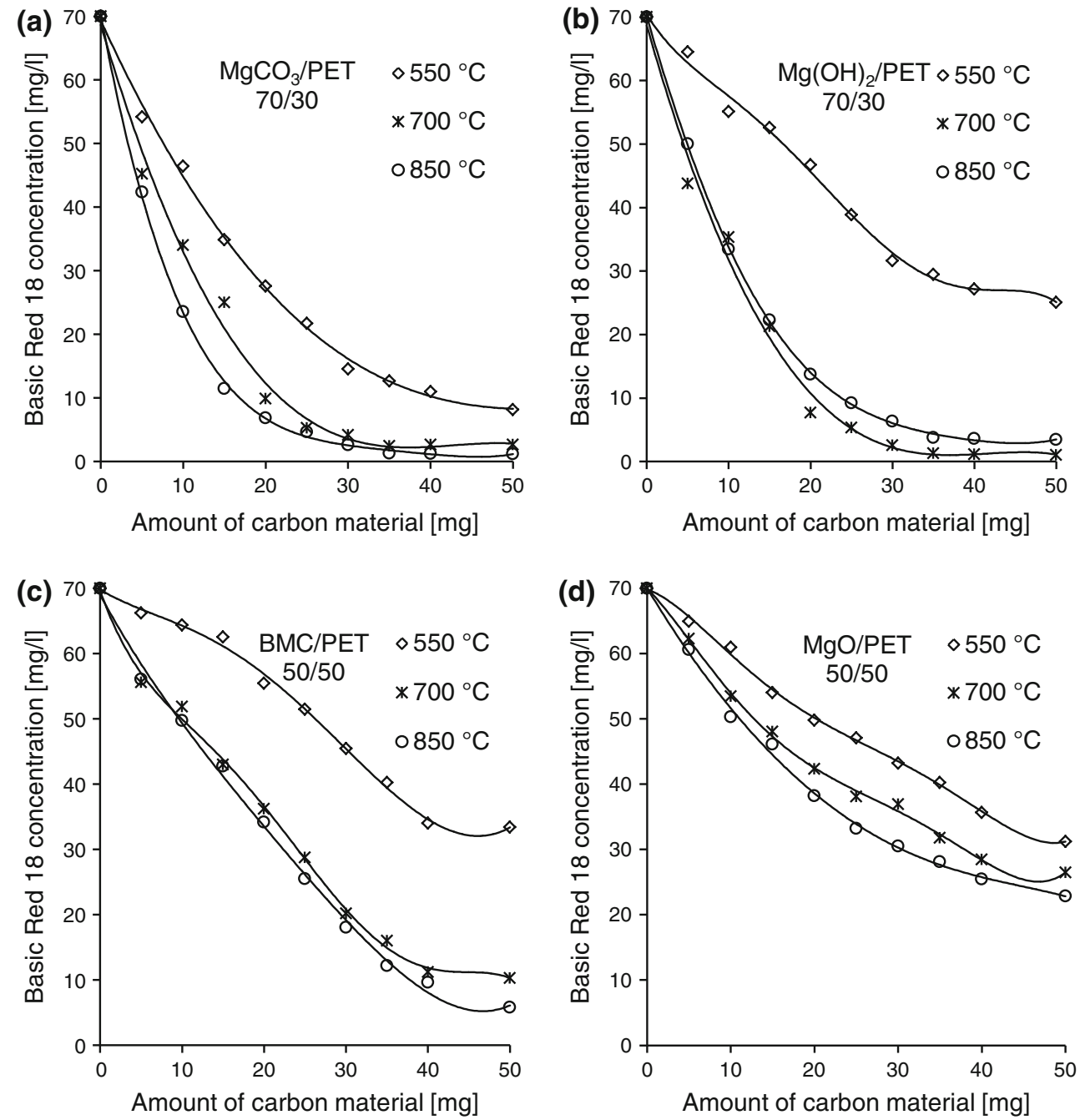
Fig. 5c, d. It is generally claimed [28] that adsorption of small molecules like phenol predominantly depends on the microporosity of sorbent materials. Hence, relatively low and comparable micropore areas and volumes (Table 1) determined for carbons prepared from $\mathrm{MgCO}_{3} /$ PET and $\mathrm{Mg}(\mathrm{OH})_{2} / \mathrm{PET}$ mixes and generally higher parameters of two other series of carbons, clearly elucidate a cause of the observed trends.

As shown in Fig. 6, uptake of phenol by the porous carbons obtained from most of the mixtures increases along with the preparation temperature. Thus, while products produced at the lowest temperature, $550{ }^{\circ} \mathrm{C}$, are of rather low adsorption capacity ( $40-60 \mathrm{mg} / \mathrm{g}$ ), uptake of phenol by porous carbons prepared at $850{ }^{\circ} \mathrm{C}$ is considerably higher and ranges from 81 to $114 \mathrm{mg} / \mathrm{g}$. In view of the data listed in Table 1, this tendency appears to be also due to the increase in micropore area and volume of the obtained adsorbents.
Adsorption capacity of various activated carbons towards phenol was reported as ranging from 35 to $150 \mathrm{mg} / \mathrm{g}$ [29-31]. Hence, performance of the carbon materials examined in this work can be considered as typical, however, strongly influenced by the preparation conditions.

\subsubsection{Removal of Basic Red 18 from water}

Performance of the obtained nanoporous carbons during adsorption of Basic Red 18 from water is illustrated by Figs. 7 and 8.

Taking into account the relatively poor effect $(86-111 \mathrm{mg} / \mathrm{g}$ ) revealed by the carbons obtained from $\mathrm{MgO} /$ PET mixtures and quite effective uptake (90-307 mg/g) of the dye by the other samples, some specific observations could be noticed. In general, uptake of the dye by carbons prepared through pyrolysis of (decomposable magnesium
Fig. 9 Adsorption of RR198 on activated carbons obtained from a $\mathrm{MgCO}_{3} / \mathrm{PET}, \mathbf{b ~} \mathrm{Mg}(\mathrm{OH})_{2} /$ $\mathrm{PET}$, $\mathrm{BMC} / \mathrm{PET}, \mathbf{d} \mathrm{MgO} / \mathrm{PET}$ mixture with different weight ratios at $850{ }^{\circ} \mathrm{C}$
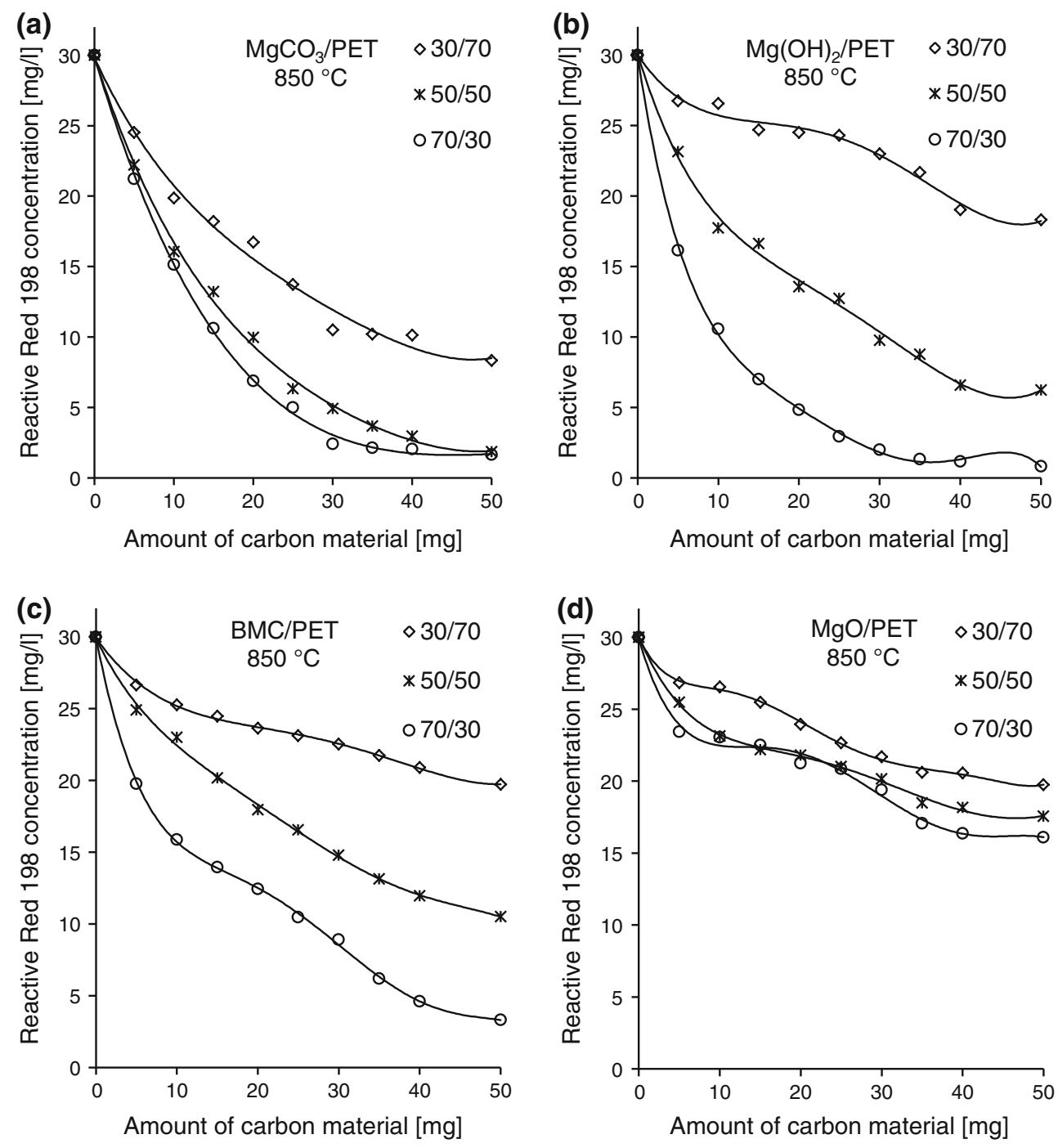
compound)/PET mixtures is superior compared to that determined for carbons obtained from $\mathrm{MgO} / \mathrm{PET}$ mixes. Moreover, while impact of $\mathrm{MgO} / \mathrm{PET}$ ratio on the BR18 removal is rather minor, performance of all the other materials substantially advances along with loadings of the inorganic components in the initial mixtures, Fig. 7. Above effect particularly concerns both $\mathrm{MgCO}_{3} / \mathrm{PET}$ and $\mathrm{BMC} /$ PET systems.

Taking into account textural parameters compiled in Table 1, distinct connection between the discussed trends and pore structure can be noticed. All the tested adsorbents demonstrate comparable micropore areas and volumes within a series. On the other hand, while the mesopore parameters determined for the $\mathrm{MgO} / \mathrm{PET}$ - based carbons are comparable, mesopore areas and volumes revealed by the other carbons substantially increase along with
(Mg compound)/PET ratio. The latter observation particularly concerns $\mathrm{MgCO}_{3} / \mathrm{PET}$ - and BMC/PET- series carbons and to a lower extent $\mathrm{Mg}(\mathrm{OH})_{2} / \mathrm{PET}$ - based ones. Hence, the mesoporosity is a key factor enhancing adsorption of the dye from aqueous solution.

Analogous trends could be found for results presented in Fig. 8. For instance, relatively poor performance of all the carbons prepared at $550{ }^{\circ} \mathrm{C}$ must be due to evidently low mesopore areas and volumes. On the other hand, similar effects revealed by BMC/PET or $\mathrm{Mg}(\mathrm{OH})_{2} / \mathrm{PET}-$ based samples prepared and 700 and $850{ }^{\circ} \mathrm{C}$ must be resulting from distinctly high and comparable mesopore parameters.

Compared to available literature data concerning adsorption of BR18 onto granular activated carbon [32], only adsorbent materials prepared from raw mixtures
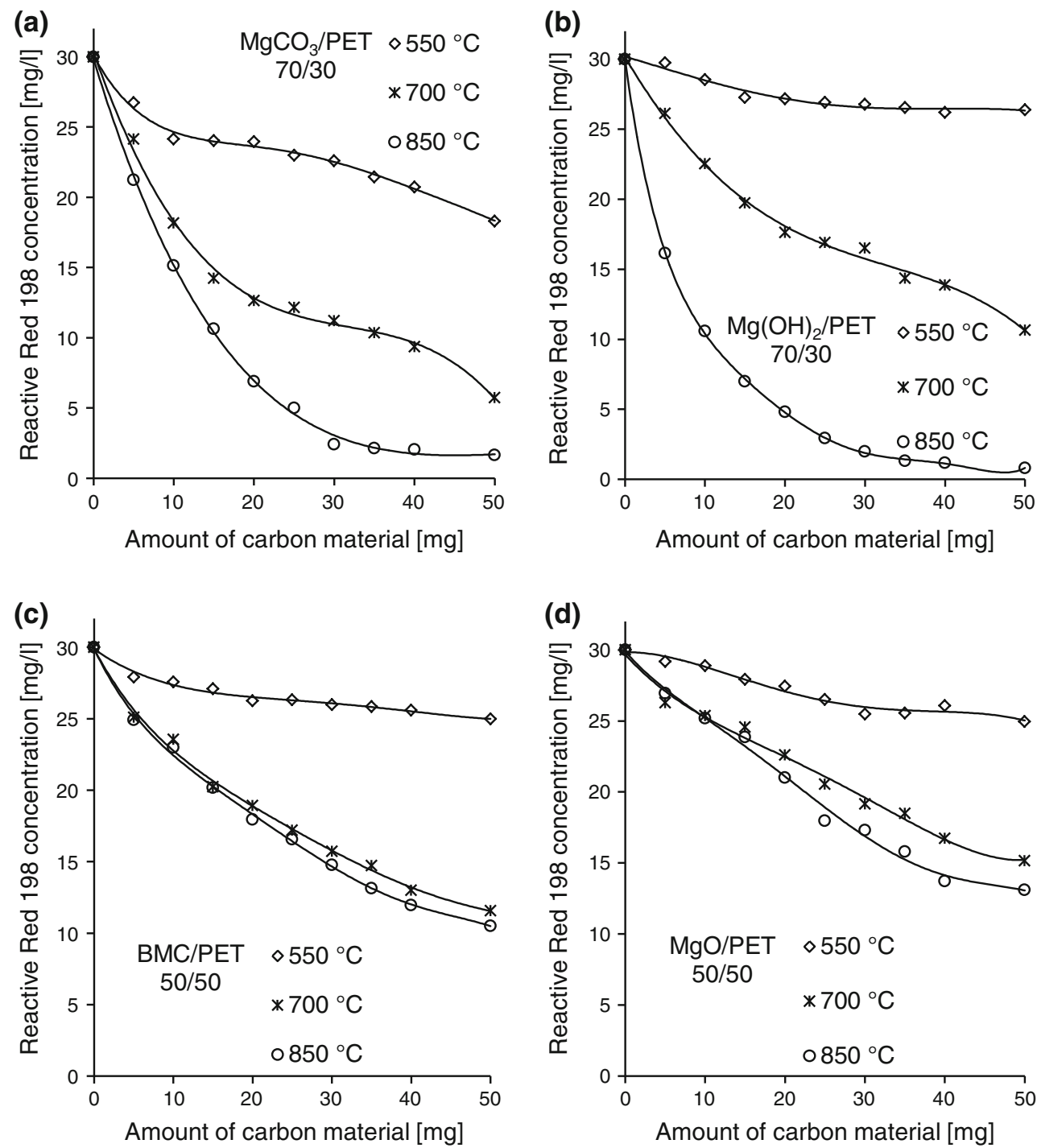

Fig. 10 Adsorption of RR198 on activated carbons obtained from a $\mathrm{MgCO}_{3} / \mathrm{PET}, \mathbf{b} \mathrm{Mg}(\mathrm{OH})_{2} / \mathrm{PET}$, $\mathbf{c} \mathrm{BMC} / \mathrm{PET}$, d MgO/PET mixtures $(70 / 30$ or $50 / 50$ ) at different temperatures 
highly loaded with the decomposable magnesium compounds reveal comparable uptake of the dye. However, performance of the studied materials towards BR 18 can be valued as superior if the effects exhibited by activated sludge $(60 \mathrm{mg} / \mathrm{g})$ [33] or by biosorbent prepared from tamarind hulls $(75 \mathrm{mg} / \mathrm{g}$ ) [34] are considered.

\subsubsection{Removal of Reactive Red 198 from water}

A series of measurements were carried out on the prepared carbons to examine adsorption of another dye, Reactive Red 198, from water. Collected results are illustrated by Figs. 9 and 10.

Despite divergent molecular weights of the dyes, the general trends observed during removal of the dye are in principle analogous to those observed for Basic Red 18. As illustrated on Fig. 9d, uptake of RR198 by MgO/PETseries nanocarbons is rather low, $10-34 \mathrm{mg} / \mathrm{g}$, and quantitative composition of the raw $\mathrm{MgO} / \mathrm{PET}$ mixtures used for preparations has a minor impact on the adsorption. On the other hand, effect of $\mathrm{MgCO}_{3}, \mathrm{Mg}(\mathrm{OH})_{2}$, and $\mathrm{BMC}$ shares in the raw mixtures on the adsorption of the dye is substantial. In each case, higher loadings of the $\mathrm{Mg}$ compounds in the raw mixtures are beneficial for obtaining porous carbons revealing higher uptake of the model contaminant, ranging from 24 to $115 \mathrm{mg} / \mathrm{g}$. In view of data presented in Table 1 it may be stated that observed trends are concurrent with those already discussed for BR18. In this way, crucial role of mesoporosity in the RR198 removal from water is confirmed. Consequently, relatively low and comparable mesopore parameters determined for the adsorbents obtained from $\mathrm{MgO} / \mathrm{PET}$ mixtures must be the reason of their poor performance, observed in spite of relatively high micropore parameters determined for these materials.

An influence of temperature used during preparations on RR198 adsorption is illustrated by Fig. 10. Regardless of combination of raw materials, strong influence of mesopore area and volume (see Table 1) on RR198 removal from water could be confirmed. Hence, particularly high uptake of the contaminant by porous carbons prepared from $\mathrm{MgCO}_{3} / \mathrm{PET}\left(70 / 30,850{ }^{\circ} \mathrm{C}\right)$ and from $\mathrm{Mg}(\mathrm{OH})_{2} / \mathrm{PET}(70 /$ $30,850{ }^{\circ} \mathrm{C}$ ) mixtures, $116 \mathrm{mg} / \mathrm{g}$ and $108 \mathrm{mg} / \mathrm{g}$, respectively, can be attributed to very high mesopore areas and volumes. Consequently, low effect $(8-30 \mathrm{mg} / \mathrm{g})$ exhibited by carbon materials prepared at the lowest temperature, $550{ }^{\circ} \mathrm{C}$, must be due to the lower mesopore parameters.

Findings discussed above confirm suitability of the studied materials for the removal of RR198 from water. This particularly concerns adsorbents prepared from PET mixed with decomposable $\mathrm{Mg}$ compounds. In comparison with results reported by others [35], RR198 uptake by the studied adsorbents can be estimated as superior compared to that measured for the char produced from sewage sludge.
Nevertheless, $\mathrm{MgO}$ nanoparticles were reported [36] to adsorb the dye quite efficiently, $76 \mathrm{mg} / \mathrm{g}$. This value can be considered as comparable to the effect revealed carbon materials prepared from PET in mixtures with BMC, $\mathrm{Mg}(\mathrm{OH})_{2}$, and $\mathrm{MgCO}_{3}$.

\section{Conclusions}

The present paper is principally aimed to investigate the suitability of carbon materials obtained from poly(ethylene terephthalate) in mixtures with different magnesium compounds, for adsorption of water contaminants of different molecular weights. As the novelty, both $\mathrm{Mg}(\mathrm{OH})_{2}$ and $\mathrm{MgCO}_{3}$ were confirmed to be suitable for preparation of porous carbon materials according to the procedure developed already for the BMC/PET systems. Thus, the choice of magnesium compounds capable to convert chars into highly porous carbons could be extended. The results presented confirmed capability of the studied carbons to adsorb various adsorbates including phenol, Basic Red 18, and Reactive Red 198. The pore structure of the adsorbents can be influenced by altering quantitative and qualitative composition of a mixture of raw materials or by varying temperature of the preparation process. Considering results of numerous tests, some hints supportive for planning preparation procedure to produce an adsorbent revealing optimal parameters for a specific application can be deduced. We believe the content of this work is an important practical complement for the more extensive research on nanoporous carbons prepared from PET contained in mixtures with various inorganic magnesium compounds.

Acknowledgments This study was supported by the Polish Ministry of Science and Higher Education, Grant No. N R050004 10. The authors wish to thank Boruta-Kolor for the dyes used in this work.

Open Access This article is distributed under the terms of the Creative Commons Attribution License which permits any use, distribution, and reproduction in any medium, provided the original author(s) and the source are credited.

\section{References}

1. B.H. Hameed, A.A. Rahman, J. Hazard. Mater. 160, 576 (2008)

2. F.C. Wu, P.H. Wu, R.L. Tseng, R.S. Juang, J. Environ. Manag. 92, 708 (2011)

3. M.A. Lillo-Ródenas, A.J. Fletcher, K.M. Thomas, D. CazorlaAmorós, A. Liares-Solano, Carbon 44, 1455 (2006)

4. S. Sumathi, S. Bhatia, K.T. Lee, A.R. Mohamed, Chem. Eng. J. 162, 194 (2010)

5. Q. Wen, C. Li, Z. Cai, W. Zhang, H. Gao, L. Chen, G. Zeng, X. Shu, Y. Zhao, Bioresour. Technol. 102, 942 (2011)

6. A. Silvestre-Albero, J. Silvestre-Albero, A. Sepulveda-Escribano, F. Rodriguez-Reinoso, Microporous Mesoporous Mater. 120, 62 (2009) 
7. T. Morishita, T. Tsumura, M. Toyoda, J. Przepiórski, A.W. Morawski, H. Konno, M. Inagaki, Carbon 48, 2690 (2010)

8. M. Benadjemia, L. Milliere, L. Reinert, N. Benderdouche, L. Duclaux, Fuel Process. Technol. 92, 1203 (2011)

9. J.M.V. Nabis, C. Laginhas, P.J.M. Carrott, R. Carrott, J. Anal. Appl. Pyrolysis 87, 8 (2010)

10. K. Yang, J. Peng, H. Xia, L. Zhang, C. Srinivasakannan, S. Guo, J. Taiwan Inst, Chem. Eng. 41, 367 (2010)

11. A. Arami-Niya, W.M.A. Wan Daud, F.S. Mijalli, Chem. Eng. Res. And Des. 89, 657 (2011)

12. S.Z. Mohammadi, M.A. Karimi, D. Afzali, F. Mansouri, Desalination 262, 86 (2010)

13. Y. Li, Q. Du, X. Wang, P. Zhang, D. Wang, Z. Wang, Y. Xia, J. Hazard. Mater. 183, 583 (2010)

14. E.N. El Qada, S.J. Allen, G.M. Walker, Chem. Eng. J. 142, 1 (2008)

15. A. Ould-Idriss, M. Stitou, E.M. Cuerda-Correa, C. FernándezGonzález, A. Macías-García, M.F. Alexandre-Franco, V. GómezSerrano, Fuel Process. Technol. 92, 261 (2011)

16. J.N. Sahu, J. Acharya, B.C. Meikap, Bioresour. Technol. 101, 1974 (2010)

17. M.C. Almazán-Almazán, M. Pérez-Mendoza, M. DomingoGarcía, I. Fernández-Morales, F.J. López, F.J. López-Garzón, Fuel Process. Technol. 91, 236 (2010)

18. J. Przepiórski, J. Karolczyk, K. Takeda, T. Tsumura, M. Toyoda, A.W. Morawski, Ind. Eng. Chem. Res. 48, 7110 (2009)

19. J.B. Parra, C.O. Ania, A. Arenillas, F. Rubiera, J.J. Pis, Appl. Surf. Sci. 238, 304 (2004)

20. M. Inagaki, H. Miura, H. Konno, J. Eur. Ceram. Soc. 18, 1011 (1998)
21. M. Inagaki, S. Kobayashi, F. Kojin, N. Tanaka, T. Morishita, B. Tryba, Carbon 42, 3153 (2004)

22. O. Terakado, M. Hirasawa, J. Anal. Appl. Pyrolysis 73, 248 (2005)

23. T. Morishita, Y. Soneda, T. Tsumura, M. Inagaki, Carbon 44, $2360(2006)$

24. L. Yan, J. Zhuang, X. Sun, Z. Deng, Y. Li, Mater. Chem. Phys, 76, 119 (2002)

25. G. Helou, S.A. Tariq, Thermochim. Acta 228, 123 (1993)

26. J. Przepiórski, J. Karolczyk, T. Tsumura, M. Toyoda, M. Inagaki, A.W. Morawski, J. Therm. Anal. Calorim. 107, 1147 (2012)

27. K.S.W. Sing, D.H. Everett, R.A.W. Haul, L. Moscou, R.A. Pierotti, J. Rouquérol, T. Siemieniewska, Pure Appl. Chem. 57, 603 (1985)

28. S.I. Kim, T. Yamamoto, A. Endo, T. Ohmori, M. Nakaiwa, Microporous Mesoporous Mater. 96, 191 (2006)

29. B. Ozkaya, J. Hazard. Mater. B129, 158 (2006)

30. J. Przepiórski, J. Hazard. Mater. B135, 453 (2006)

31. P. Ariyadejwanich, W. Tanthapanichakoon, K. Nakagawa, S.R. Mukai, H. Tamon, Carbon 41, 157 (2003)

32. B. Noroozi, G.A. Sorial, H. Bahrami, M. Arami, Dye. Pigment. 76, 784 (2008)

33. O. Gulnaz, A. Kaya, F. Matyar, B. Arikan, J. Hazard. Mater. B108, 183 (2004)

34. S. Khorramfar, N.M. Mahmoodi, M. Arami, K. Gharanjig, Color. Technol. 126, 261 (2010)

35. C. Jindarom, V. Meeyoo, B. Kitiyanan, T. Rirksomboon, P. Rangsunvigit, Chem. Eng. J. 133, 239 (2007)

36. G. Moussavi, M. Mahmoudi, J. Hazard. Mater. 168, 806 (2009) 